\title{
Ke smyslu a konstrukci sociologických teorií
}

\author{
Making Sense of Sociological Theories and Their Construction \\ Ilja Šrubař
}

\begin{abstract}
As self-descriptions of societies social theories in general represent constituent parts of the social reality itself. Considering this, the following study focuses on three points: It sheds light on the role of social theories within their scientific and societal context, next it discusses implications resulting from the structure of social reality for the construction of theoretical concepts, and finally it makes efforts to formulate some criteria that adequate social theories should meet.
\end{abstract}

KEYWORDS social theories, self-organization of society, metatheory, action, structure.

Předmětem této stati je osvětlení pozice sociálněvědných a zvláště sociologických teorií v jejich vědeckém i společenském kontextu a diskuze problémů, které při jejich konstrukci vyplývají ze struktury jejich předmětu, jehož částí zároveň jsou. Cílem je formulace kritérií, které by měly v optimálním př́padě tyto teorie splňovat.

O smyslu a účelu vědeckých teorií píše v roce 1934 Karl Popper ve své Logice zkoumání: „Teorie je sít', kterou rozhazujeme, abychom v ní zachytili ,svět‘, dali mu racionální podobu, vysvětlili ho a ovládli“ (Popper 1973: 31). Teorie je takto model uvádějící empirická zjištění do jistých rozumem kontrolovatelných souvislostí a nabízející možné odpovědi na otázky, se kterými je výzkumník svými empirickými nálezy konfrontován. Teoretické modely nabízejí pojmy a souvislosti, jimiž jsou empirická data ve svém možném významu definována, a určují tak pole dalšího výzkumu. Jak již exemplárně ukázal Thomas Kuhn (1996), jsou „empirická fakta“ v tomto smyslu vždy již teoretickými konstrukty a význam jejich výpovědi se mění podle toho, jakým teoretickým paradigmatem jsou vykládána. „Viděl-li vědec před změnou paradigmatu ve všem kachny, nachází po ní všude králíky,“ ř́íká ironicky Kuhn, aby ten stav věcí ilustroval (1996: 111). Sociologovi socializovanému v teoretickém světě oboru, v němž existuje paralelně řada takových paradigmat, je tato situace důvěrně známa. Stačí se kupř́kladu podívat na to, jak se proměňuje podoba společnosti podle toho, jakou teorii použijeme k výkladu sociální nerovnosti, kterou empiricky zjišt’ujeme. V rámci marxistického paradigmatu dostáváme společnost dvoutřídní s různými funkčními uskupeními uvnitř tříd, které stojí v antagonistickém konfliktu. V klasickém stratifikačním modelu, opírajícím se o Parsonse (1967), měřícím př́ijem, vzdělání, status a vliv, se společnost jeví jako

Sociálni studia. Katedra sociologie FSS MU, 1/2012. S. 15-28. ISSN 1214-813X. 
hierarchický žebříček sociálních vrstev, propojených jistou mírou mobility. V „postmoderní“ optice teorie sociálních prostředí a životních stylů (Hradil 1987) se pak společnost zdá být propletencem heterogenních skupin s různými životními orientacemi.

Kuhnův teoretický relativismus je však bržděn už v Popperově koncepci poukazem $\mathrm{k}$ tomu, že teorie musí být falsifikovatelné. $\mathrm{K}$ tomu patř́ jednak jejich formulace, umožnuující kontrolu jejich výstavby, ale především konfrontace jejich výpovědí s objektem, na který se vztahují. Zde samozřejmě narážíme na shora ilustrovaný paradox, zdůrazňovaný konstruktivistickými relativisty, plynoucí z toho, že podoba předmětu teorie je formována teoretickými předpoklady, které do empirického výzkumu tohoto předmětu vstupují. Tato cirkularita vědeckého postupu není pouze formálním následkem logické výstavby teorií, v níž platnost axiomů určuje platnost odvozených vět. V případě sociálních věd má tato cirkularita i hlubší, dalo by se říci ontologické, odůvodnění, o němž bude řeč později. Přesto však, jak Popper (1973) ukazuje, mohou empirická zjištění vyžadovat takovou míru modifikací axiomů výchozí teorie, že tato ztrácí svou opodstatněnost. Sociologickým příkladem mohou být opět nepřekonatelné problémy, před kterými stáli němečtí výzkumníci, když se snažili přizpůsobit Marxovu teorii sociální nerovnosti realitě německé společnosti 60. a 70. let minulého století (Klassenanalyse 1975), v níž roli proletariátu prrebírali studentští revolucionáři, zatímco pomalu mizící a občansky integrovaná dělnická třída revoluční hnutí ignorovala či vysloveně odmítala. Vidíme tedy, že i když teoretické předpoklady orientují směr empirického zkoumání, mohou jeho výsledky vést ke změně teoretické konstrukce. Obecněji formulováno: Je-li empirie bez teorie slepá, pak je teorie bez empirie prázdná. Součinnost obou těchto procesů zkoumání je tedy nezbytná. V tom - zdá se - je teoreticky jasno, i když praxe často vypadá jinak.

Vědecká skutečnost je tedy vždy formována teorií, teorie však nachází v konfrontaci i s takto formovanou skutečností své hranice. Tato vzájemná souvislost forem teorie a jejího předmětu je podstatná v epistemologii jak př́rodních, tak sociálních věd. Ale její relevance v obou oborech hraje podstatnou roli pro konstrukci teorií i pro chápání jejich předmětu. Již Popper poukazuje na to, že teorie není zrcadlem skutečnosti, ale nástrojem, který dává světu racionální a tudíž člověku př́stupnou podobu. I když tento v principu kantovský přístup lze považovat za obecně platný, přesto nám umožňuje vidět, že mezi takto tvořeným předmětem prírodních a sociálních věd existuje podstatný rozdíl, který Simmel ve své Sociologii z roku 1908 formuloval takto: „Zásadní rozdíl mezi souvislostí společnosti a souvislostmi v př́rodě je ten, že ty poslední - vycházíme-li z Kantova pohledu - jsou výhradně výtvorem nahlížejícího subjektu, zatímco souvislost vědomě a integrativně jednajících částí společnosti se uskutečňuje sama sebou a nevyžaduje syntetizující [vědecký, poznámka I.Š.] náhled pozorovatele. Kantova věta, podle které souvislosti nejsou vlastností pozorovaného předmětu, ale produktem pozorujícího subjektu, v př́ípadě společenských souvislostí neplatí, protože tyto jsou vskutku výtvorem předmětu“" (Simmel 1968: 22-23).

Pro tvorbu sociálně-vědných/sociologických teorií má tento poznatek dvě zásadní konsekvence:

1. Sociologické teorie jsou konfrontovány s předmětem, který vykazuje v nejširším smyslu „racionální“, tj. na základě lidské vědomé aktivity vznikající, strukturu a řád jednání, a tedy smysluplnou, subjekty vytvářenou a pochopitelnou souvislost, existující nezávisle na tom, 
jakou formu této souvislosti dá vědecký pozorovatel. Společenští aktéři jednají na základě svého předvědeckého ,pozorování prvního řádu“ (Luhmann 1990: 68 nn.) a vytvářejí tak sebepopis společnosti z toho plynoucí. I na úrovni každodenních společenských procesů platí, že forma sebepopisu společnosti utváří strukturu její regulace, která zpětně vymezuje hranice a možnosti tohoto sebepopisu. Je to tedy toto primární pozorování, které je základem společenské regulace a autogeneze ${ }^{1}$ sociálního pořádku, který se pak stává předmětem sociologie.

2. Sociologické teorie nahlížející tuto sebeorganizaci představují pozorovatele druhého řádu. Jsou tak zároveň také součástí sebepopisu společnosti, tj. součástí svého předmětu a podílejí se samozrejmě i na formování svého předmětu jak v oblasti vědecké, tak i v rámci autogeneze společnosti jako celku. Toto zjištění nelze ovšem považovat za jakousi legitimaci pozitivistického optimismu, doufajícího ve vědeckou ovladatelnost společnosti. Vypovídá pouze o tom, že i sociologické teorie jsou součástí společenského diskurzu a takto producentem rezervoáru pojmů, koncepcí a modelů, které mohou být diskurzem uchopeny, formovány a často i překvapivým, nezamýšleným způsobem proměněny v motivaci jednání osob a institucí. ${ }^{2}$

Vidíme tedy, že vztah sociologických teorií k jejich předmětu je shora uvedenými okolnostmi značně komplikován. Při konstrukci těchto teorií nejde jen o metodickou adekvátnost jejich formulace ve smyslu Popperově, ale i o adekvátnost jejich konstrukce ve vztahu ke struktuře jejich předmětu. Požadavek zohlednění struktury sociální reality, jejíž jsou teorie částí, neznamená zajisté, že by měly být teorie formulovány jaksi již s ohledem na svůj politický dopad. Znamená to pouze, že teorie nejsou zcela volné při konstrukci svých modelů a nemohou svá kategoriální schémata a jimi modelované a vysvětlované vztahy a souvislosti podkládat společenské realitě bez ohledu na její autogenetickou strukturu. Nemohou se spoléhat na to, že je to teprve jejich model, který objasňuje, co vlastně společnost dělá, nýbrž musí zacházet s faktem, že jsou zde komplexní souvislosti společenského jednání a procesů, které se regulují samy na základě svých vlastních modelů a výkladů svého okolí či „,světa“ jako celku. Má-li být sociologická teorie adekvátní, musí tento stav věcí ve své architektuře zakotvit.

Zde ale narážíme na další obtíž při tvorbě sociologických teorií: Není totiž zcela jasné, jak vymezovat hranice mezi tím, co je na lidské skutečnosti „sociální“, a tím, co na této skutečnosti spadá do oboru jiných věd. Historicky vzato, pramení tato nejistota ze sporů o specifický předmět vznikající sociologie, které se vedly na přelomu 19. a 20. století. Do aktuální debaty o konstrukci sociologických teorií se tato problematika promítá jako diskrepance mezi teoriemi jednání a „strukturálními“ teoriemi a v důsledku této diference jako problém vztahu individua a společnosti vůbec. Tradičně zde jde jak známo o to, má-li být sociální skutečnost chápána jako produkt jednání individuí, která ji svou interakcí a komunikací konstruují,

1 Používám zde termín „autogeneze“ místo Luhmannovy „autopoiese“, protože i „nesystémové“ teorie tento proces tematizují a vycházejí z něj, jak je vidno i z citované úvahy Simmelovy. Termín „autogeneze“ tak označuje proces seberegulace společnosti jako takový, aniž by již stál v určitém teoretickém kontextu. K tomu viz Šrubař (2007).

2 To, co je zde řečeno o sociologických teoriích, platí o všech teoretických výpovědích modelujících fungování společnosti, tedy i o modelech ekonomických či ekonomizujících, u kterých tuto pozitivistickou představu implicitně nacházíme (k tomu Sedláček 2009, ale již Pareto 1980). 
nebo má-li se sociologie zabývat pouze výsledkem těchto procesů, tj. strukturami nadsubjektivního charakteru, regulujícími jednání jednotlivců a vystupujícími vůči nim jako na nich nezávislá, objektivní skutečnost „sui generis“ ve smyslu Durkheimově (1895). Aktuálním rozšířením debaty je diskuse o tom, je-li sociální realita výhradně výsledkem interakce lidských subjektů, nebo je-li třeba zahrnout do sociologické teorie i lidskou interakci s objekty př́rodními a artefakty, jak to kupř́ikladu požaduje koncepce „quasi-objektů“, kterou formuluje Latour (2008) a jeho následovníci v takzvané „Actor Network Theory“ (Latour 1996).

I zde je tedy zřejmé, že teoretická rozhodnutí mají podstatný vliv na podobu společnosti jevící se v té či oné optice, a tím i na „technické“ nároky na konstrukci dané teorie a na zaměření jí orientovaného výzkumu. Jak selektivní tato optika může být, vidíme na právě uvedeném prŕkladě: Na základě teoretických rozhodnutí o tom, co vlastně do sociální skutečnosti patří, si podobu „sociálního“ jako předmětu teorie můžeme schématicky představit jako tři koncentrické množiny. V centru se nachází „společnost“ jako nadsubjektivní/objektivní struktura sociálních institucí a vztahů v nejširším smyslu tak, jak ji koncipují teorie strukturální. Toto centrální jádro je rozšîř́eno o procesy interaktivní konstrukce této struktury jednajícími subjekty tak, jak to vidí teorie jednání. A konečně třetí množina obsahuje sociální struktury, subjekty, další živé bytosti i objekty, které rovněž do interaktivní konstrukce sociální reality vstupují.

Obrázek 1: Typy teorií a jejich pojetí předmětu sociologie

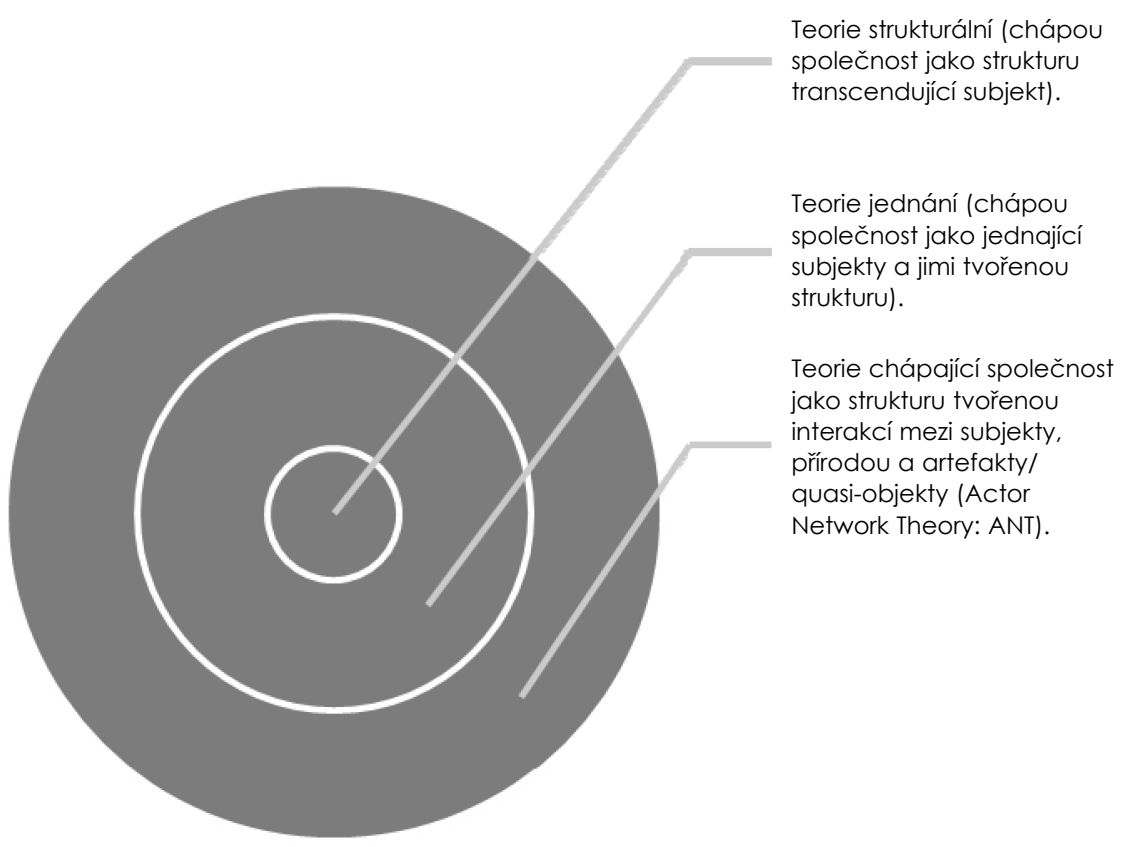


Kdybychom jednoduše akceptovali kteroukoliv z těchto podob sociální skutečnosti, vstoupili bychom do okruhu odpovídajících teorií, a tedy i do axiomatické logiky s nimi spojené, a o kritériích potřebných pro konstrukci adekvátní sociologické teorie by tím bylo již rozhodnuto. Pro posouzení takových kritérií, či přesněji, pro formulování otázek, na které by sociologická teorie měla odpovědět, je tedy třeba najít východisko ležící jaksi mimo zmíněné okruhy - čili, máme-li opět použít Luhmannovy metafory, vystoupit na metateoretickou pozorovatelnu třetího stupně. Ani zde se však nemusíme vrhat do divokých spekulací, nýbrž můžeme vyjít ze základní otázky, kterou si sociologie jako orgán sebepopisu moderních společností již od svých počátků kladla a která ve formulaci Simmelově zní: „Jak je společnost vůbec možná?“ (Simmel 1968: 21 nn.). ${ }^{3}$ Položíme-li výchozí otázku sociologické teorie v této obecnosti, pak lze ovšem říci, že všechny teoretické i empirické výpovědi představují možné elementy jejího řešení. To samozřjejmě platí i pro uvedené typy teoretických koncepcí, které jsou rovněž rovinami a variantami možné odpovědi. I když každá z těchto koncepcí je v rozsahu své odpovědi v určité míře omezená, formuluje přesto problémy, jejichž řešení je pro celkovou odpověd' nezbytné a které sociologická teorie musí tím či oním způsobem zohlednit.

Píšeme-li zde o „celkové odpovědi“, je třeba určit teoretickou rovinu, na které se tak nacházíme. Zde nám může být nápomocno Giddensovo rozlišování mezi „sociální teorii““, odpovídající na Simmelovu otázku, a teorií společnosti, aplikující koncepty sociální teorie na určitou historickou sociální formaci (Giddens 1999: xvii). Na úrovni sociální teorie se otázka ,jak je společnost možná“ klade jako otázka po konstrukci sociální reality a jejích základních procesech. Jednotlivé elementy tohoto konstitutivního procesu a z toho plynoucí otázky lze ovšem vymezit pouze komparativně. Teprve ve srovnání různých typů teoretických koncepcí a jejich explicitních i implicitních předpokladů se ukazují přednosti i nedostatky jejich vysvětlujícího potenciálu, a tím i potřeba korektury či doplnění jejich axiomatiky z perspektivy koncepcí alternativních.

Jednou z prvních teoretických studií, systematicky používajících tuto komparativní techniku teoretického výzkumu, byla Parsonsova Struktura sociálního jednání (1968). Srovnávána byla, jak známo, teorie Weberova, Durkheimova, Paretova a Marshallova, tedy jak teorie jednání, tak teorie strukturálního typu. Ze závěrů tohoto srovnání později vyplynulo Parsonsovo pojetí sociálního systému jako udržující se rovnováhy různých rovin společenských formací, která se dynamicky sama obnovuje. Z hlediska konstrukce sociologických teorií je zde důležité, že Parsons pozoroval jistou souběžnost srovnávaných teorií, kterou označil jako jejich konvergenci. Tato konvergence poukazuje opět k tomu, že variabilita sociologických modelů je omezena implikacemi jejich předmětu i přes to, že tento je formulován na základě odlišných teoretických rozhodnutí. Tyto implikace si vynucují jisté překrývání teorií jednání a teorií strukturálních, které se promítlo do Parsonsova předpokladu zřetězení různých procesů, jež je možno považovat za konstitutivní elementy sociální reality. Na rozdíl od pozdější Luhmannovy teorie systémů považoval Parsons sociální realitu za výsledek jednání (Parsons 1951), i když jasně viděl, že faktory, které lidské jednání, a tím

K jak radikálním přehodnocením sociologické teorie může tato otázka vést, vidíme na teorii autopoietických systémů, kterou na ni odpovídá Niklas Luhmann (1981). 
i konstrukci sociální reality, umožňují, nutně přesahují oblast prosté interakce. Jeho pozdní koncepci „kybernetických vztahư“ v systému jednání (Parsons 1966: 5 nn., 28) můžeme považovat za popis koloběhu různých procesů a jejich funkcí, v jejichž spojení se autogeneze sociálního řádu uskutečňuje. Klíčovým momentem je pro něj propojení jednání aktérů s rámcem jeho systémových podmínek vytvářených institucemi. Schopnost jednání, založená na psychicko-organickém vybavení subjektů, je předpokladem pro konstrukci reality par excellence - naplňuje, obrazně, společnost energií a životem. Dle Parsonse je tato schopnost formována na různých stupních socializací, systémem sociálních norem a konečně „,kulturou“ jako „poslední realitou“, přičemž je tyto stupně třeba chápat jako institucionalizované výsledky jednání samotného. Takto vytvářené instituce zároveň reprezentují různé stupně kontroly jednání. Kultura formuje systémy norem, tyto kontrolují socializaci, ve které je přebíráním patřičných rolí utvářena osobnost, jejímž jednáním se systém reprodukuje.

I když se Parsons (1975: 67, poznámka na s. 68) sám hlásil ke Kantově pojetí teorie, diktující svému predmětu pravidla rozumu, jeho teze o konvergenci sociologických teorií poukazuje $\mathrm{k}$ tomu, že představa do sebe uzavřeného okruhu, v němž sociální jednání samo vytváří pravidla a instituce své kontroly, a tím i podmínky produkce a reprodukce sociální reality, není pouhou teoretickou konstrukcí v Kantově smyslu, nýbrž že je podmíněna i implikacemi svého předmětu, jehož je sebepopisem. Není tedy náhodou, že tuto představu autogeneze sociální reality nacházíme u mnoha dalších teoretických konceptů, a to i takových, které Parsonsově koncepci sociálního systému důrazně oponují. Zvláště zřetelně lze předpoklady takové autogeneze sledovat v teoriích, které se - podobně jako Parsons - snaží syntetizovat strukturální př́stup s perspektivou teorie jednání, i když kritizují jednostrannost strukturální a interakcionistické perspektivy.

Bourdieho základní teoretický model propojení systémových struktur, habitu a praxe individuálních či kolektivních životních stylů je zároveň i deskripcí koloběhu reprodukce systémových struktur na základě socializace, i když s jednoznačně kritickým společenským záměrem (Bourdieu 1984: 277 nn.). Sociální struktura, reprezentovaná strukturou společenského kapitálu, formuje habitus, motivující praxi, v níž se sociální nerovnost přístupu ke kulturnímu, sociálnímu a ekonomickému kapitálu, a tím i struktura společnosti reprodukuje. I zde tedy nacházíme rovinu strukturální a rovinu jednání propojené procesem habitualizace, ve kterém se formuje orientace jednání pod vlivem sociálních faktorů. I Giddensova Konstituce společnosti řeší problém vztahu jednání a systémových struktur základním axiomem, který - zjednodušeně - praví, že ,jednání vytváří struktury a struktury regulují jednání“ (Giddens 1999: xxi nn., 2nn.). Na základě toho považuje Giddens výstavbu společnosti za popsatelnou jak v termínech teorie jednání, tak termínech teorií strukturálních, přičemž jsou oba př́istupy ekvivalentní. Syntetizující teorie konstituce společnosti musí tedy uchopit tento proces dvojí tvorby struktur, tj. jak strukturu jednání, tak strukturu systémovou, a jejich vzájemné propojení komunikací (Giddens 1999: 28 nn.). Komunikace ve formě interakce a řeči tak, jak ji chápe Giddens, hraje centrální roli v pokusu o uchopení procesu konstrukce sociální skutečnosti, který na základě Schützovy teorie smysluplné konstituce sociálního světa (Schütz 2004) a Meadova interakcionismu (Mead 1970) již klasicky formulovali Berger a Luckmann (1966). Autoři podrobně analyzují stabilizaci a diferenciaci vzorců sociálního jednání a vědění v procesu jejich jazykové reprezentace. Pokoušejí se tím osvětlit přechod 
autogeneze sociální reality z roviny individuálního jednání a interakce ke komplexnějším formám sociálního řádu v podobě rolí, dělby práce atd. Z hlediska konstruování sociologické teorie je zde významné to, že Berger a Luckmann ukazují, že nestačí vymezit faktory fungující jako konstitutivní elementy $\mathrm{v}$ autogenezi sociální reality, ale že je zapotřebí i výpovědí o procesech emergence, které tyto elementy propojují. Tento problém generalizuje Luhmann, když ř́ká, že sociální teorie jsou validní jen tehdy, jsou-li schopné uspokojivě vyřešit problém „strukturálního propojeni““ mezi jednotlivými systémy, které se na autogenezi sociální reality podílejí (Luhmann 1997: 100 n.). Luhmannův návrh takového řešení je ovšem komplikován tím, že psychické a sociální systémy jsou sice na jedné straně spojeny řečí, na straně druhé ale řeč sama nemůže být druhem komunikace, protože komunikace je výhradně formou autopoiese sociálních systémů a nemůže tak překročit jejich hranice (Luhmann 1985: 191 nn., 1997: 205 nn.). Avšak i v rámci tohoto omezení nacházíme i u Luhmanna představu stupňování a koloběhu forem či rovin sociální skutečnosti, zřejmou již z jeho dělení sociálních systémů na interakce, organizace a společnosti, propojených mezi sebou různými formami komunikace (Luhmann 1985: 16).

Kdybychom tedy měli zhruba načrtnout základní model autogeneze sociální reality, na jehož pozadí současné sociologické teorie na otázku ,jak je společnost možná“ odpovídají, došli bychom zřjejmě k následujícímu schématu:

Obrázek 2: Model autogeneze sociální reality

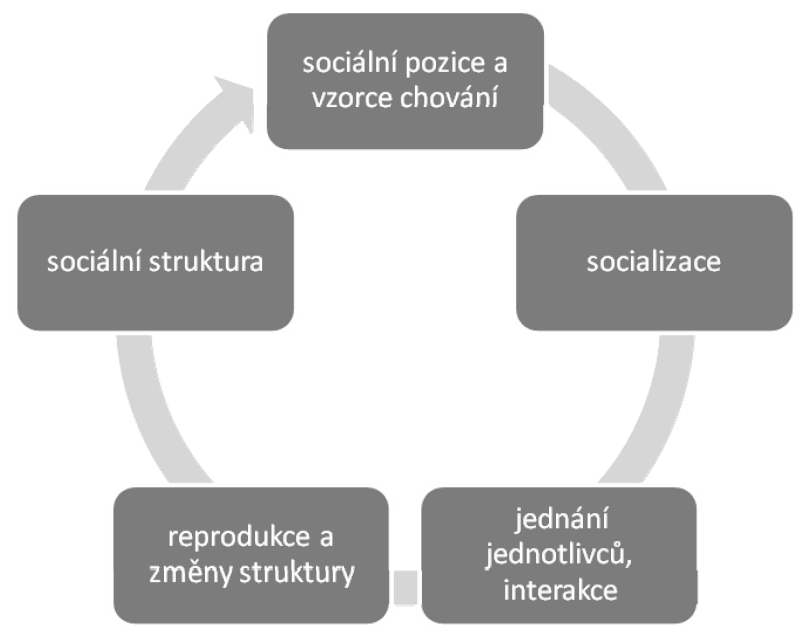

Akceptujeme-li toto znázornění, můžeme říci, že diference mezi jednotlivými typy sociologických teorií jsou dány volbou výchozího bodu, z něhož se odpověd' na zadanou otázku odvíjí. Výstavba „strukturálních“ teorií vstupuje do tohoto autogenetického koloběhu analýzou a modelováním procesů na horních rovinách schématu, a teprve potom se zabývá jejich zpětnými vazbami a propojením s rovinou dolní, které často postuluje jen obecně nebo je pouze předpokládá. Teorie jednání naopak vstupují do autogenetického okruhu na jeho 
bazální úrovni, tj. na úrovni jednání a interakce, které chápou v úzkém spojení s procesy reprodukce a změny struktury. Následně se snaží modelovat stoupající komplexitu a stabilizaci interakcí a komunikace až $\mathrm{k}$ formám organizací a celospolečenských institucí. Směr výstavby, kterým řídí svou teoretickou architekturu, je tedy zřejmě protichůdný ke směřování teorií strukturálních, i když se oba prrístupy pohybují - metaforicky řečeno - po stejné dráze, vyznačené tím, co jsme označili jako implikace předmětu sociologie, jehož jsou teorie částí. Zde nacházíme i důvod pro to, proč je tvorba sociologických teorií charakterizována růzností paradigmat jejich optiky. Není to chybějícím náhledem do systematických souvislostí výstavby společnosti, ale spíše následkem různých teoretických rozhodnutí o tom, kde do analýzy autogenetického kruhu konstrukce sociální reality vstoupit. Z toho pak nutně vyplývají odlišné konsekvence pro výstavbu teoretických modelů a jejich empirického ověřování.

Variace tvorby teoretických modelů není tedy neomezená. Jak bylo shora ukázáno, musí sociologická teorie, at’ už je vedena jakýmkoliv směrem, řešit či alespoň tematizovat následující problémy:

1. Problém motivů jednání: Teorie musí formulovat předpoklady týkající se orientace jednání, tj. musí vypovídat o momentech, které jednání individuí motivují a usměrňují.

2. Problém konstituce společného vědění: Dále musí teorie obsahovat řešení toho, jak vznikají společné vzorce sociálního jednání a jeho orientace.

3. Problém sociálních struktur: Teorie musí modelovat mechanismy, které společné vzorce jednání stabilizují, tj. kterými je vytvářena struktura sociálních pozic, jimi spojených očekávání a jejich diferenciace do institucí a organizací.

4. Problém sociálních změn: Musí být řešena otázka reprodukce a dynamiky sociálních struktur.

5. Problém propojení rovin: Vychází-li sociologická teorie $\mathrm{z}$ toho, že se její předmět konstituuje autogeneticky, pak musí předpokládat souvislosti mezi rovinami této autogeneze uvedenými v bodech 1 až 4 . Musí tedy obsahovat výpovědi o způsobu jejich vzájemného propojení.

6. Problém ,,autologického “ charakteru sociologických teorii: ${ }^{4}$ Konečně se musí sociologická teorie metodologicky vypořádat $\mathrm{s}$ faktem, že je sama částí svého předmětu. Musí nebo by alespoň měla - reflektovat způsob, jakým se struktura předmětu promítá do struktury teorie, tj. za jakých podmínek se teorie sama může považovat za svému předmětu adekvátní.

Momenty tohoto autogenetického kruhu musí být zohledněny ve všech typech sociologických teorií. Přitom není rozhodující, má-li metodologický postup preferovaný danou teorií charakter nomologický nebo idiografický, interpretativní. Již Rickert (1913) ukázal, že sociologie je „hraniční“ vědou, v níž mohou být užity oba prŕstupy. To je zrrejmé i v současném spektru sociologických teorií, kde jsou oba koncepty zastoupeny jak mezi teoriemi jednání, tak mezi prrístupy strukturálními. ${ }^{5}$ Uvedené problémy nejsou samozřejmě řešeny

Viz k tomu Luhmann (1990: 7 nn.), ale paradigmaticky už Mannheim (1969: 242).

Př́sně nomologický prístup si nárokují - na rozdíl od teorií interakcionistických - teorie založené na principu racionální volby (kupříkladu Coleman 1995, Esser 1991 ad.). Ze strukturálních 
ve všech teoriích vždy všechny najednou a se stejnou intenzitou. Často představují jen horizont, před kterým jsou jisté body intenzivně osvětlovány, zatímco ostatní uvedené momenty a souvislosti platí jako latentní předpoklady ve smyslu ceteris paribus. Strukturální prŕístupy se zřejmě koncentrují na body 3 a 4, zatímco teorie jednání osvětlují tematické okruhy uvedené v bodech 1 a 2 . I zde opět vidíme, jak široké pole se pro variaci teoretických paradigmat i v takto systematizovaném rámci sociologického zadání otevírá. Zde nabízená systematizace nám ale může sloužit jako tertium comparationis, které nám umožní, abychom se v houštině sociologických teorií lépe orientovali. Lze ji použít jako matrici ke srovnání jednotlivých konceptů, na jejímž pozadí se ukazuje rozsah a hloubka jejich záběru i stupeň systematického zpracování jednotlivých tematizovaných momentů. Můžeme tak zviditelnit jak rozsah explicitních výpovědí, tak i latentní ,podhoubí “ činěných předpokladů, které sice teoretickou koncepci podpírají, ale zůstávají neřešeny. A samozřejmě můžeme i odhalovat systematické nedostatky teoretických konstrukcí tam, kde řešení jimi explicitně kladených klíčových otázek chybí. Touto cestou tedy lze porovnávat pojmové instrumentárium jednotlivých přístupů a vybírat to nejvhodnější pro rozpracování konkrétních empirických zadání.

Avšak at' už je fokus sociologických teorií na prvních čtyřech uvedených rovinách zaměřen kamkoliv, řešení posledních dvou problémů - tj. propojení rovin a problému svého ,autologického" charakteru - se vyhnout nemohou. Vzhledem k tomu, že se jedná o problémy obecného charakteru, se kterými je konfrontována každá sociologická teoretická konstrukce, bude vhodné se podívat na jejich typická řešení. Pomineme-li řešení málo specifická, jak je nabízejí sociologové první generace ve formě Durkheimovy „solidarity“ (Durkheim 1960) nebo Spencerovy organické „diskrétní součinnosti“ částí sociálního celku (Spencer 1885), nacházíme v rozvíjející se sociologické teorii 20. století dva typické mechanismy propojení rovin autogeneze sociální reality. První vychází z teorie jednání a spatřuje ,propojení“ v různých formách interakce, jak je nacházíme u Simmela, Webera, Schütze, popř́padě na druhé straně Atlantiku u Meada. Druhý, částečně ve stopách Spencerových, vychází z propojení různých částí sociálního celku, které je nutné pro fungování celku jako systému, a je paradigmaticky reprezentován teorií Parsonsovou. Oba mechanismy však narážejí na deficity omezující rozsah jimi nabízených vysvětlení, vyplývající z logiky jejich konstrukce. Interakčním modelům chybí zpočátku koncepty, které by objasňovaly stabilizaci a institucionalizaci společných vzorců jednání v čase. Tento nedostatek odstraňuje Mead a současně i Schütz chápáním interakce jako sémiotického procesu, ve kterém jsou vzorce chování vytvářeny a reprezentovány na úrovni znaků a především jazyka, čímž získávají charakter sociální reality existující v čase nezávisle na intencích jednotlivých aktérů. Představa komunikace jako mechanismu konstituce a propojení rovin autogeneze sociální reality zde nabývá své první obrysy. I Parsonsovo paradigma funkcionálního propojení systémových částí bylo konfrontováno s teoretickými obtížemi. Parsonsova koncepce se bezpochyby snaží obsáhnout všechny roviny konstituce sociální reality. $\mathrm{V}$ představě systému jako interakce jeho částí je také moment komunikace vždy již zahrnut. Tato „kybernetická“ verze komunikace (Parsons 1966: $28 \mathrm{nn}$.) jako přenosu informace od části k části naráží ovšem v př́ípadě sociálního systému

koncepcí tendují k nomologickému postupu teorie systémů nebo je nomologický a interpretativní př́stup kombinován. Jako př́klad posledního může sloužit Bourdieova praxeologie. 
na problematickou skutečnost, že nelze jednoznačně určit kde, jak a jaké informace v sociálních systémech vznikají. Parsonsova pozdní reformulace komunikace jako vzájemné ,interpenetrace“ subsystémů problém jen posunula, ale neřešila. Teprve Luhmannovo „obrácení“ systémové optiky, kde komunikace představuje základní proces tvorby i propojení elementů sociálních systémů, jehož formováním systém teprve nabývá svou specifickou podobu, se zdá být řešením propojení rovin autogeneze sociální reality, které tak odstraňuje nedostatky systémové teorie. Za toto řešení však Luhmannova koncepce platí vysokou cenu: Tím, že je proces komunikace uzavírán do hranic sociálního systému, se přerušuje kontakt mezi sociální realitou a subjektem, který se tak jako ,psychický systém“ ocitá mimo záběr takto koncipované sociologické teorie, čímž je problém ,propojení“ jednání a struktury znovu otevřen.

Nicméně vidíme, že oba typy řešení problému ,propojení“ vykazují ve svém vývoji jistou konvergenci. Názorným výrazem této konvergence je kupř́ikladu Habermasova teorie komunikativního jednání (Habermas 1981), v níž je problém propojení interaktivní a systémové komunikace formulován jako výchozí otázka teorie společnosti. Komunikace je tedy různými typy teoretických řešení tematizována jako základní proces konstituce sociální reality, který prochází všemi jejími rovinami a vytváří tak realitu strukturovanou smyslem. $\mathrm{Na}$ otázku, kde se vlastně bere „informace“ v sociálních systémech, tak odpovídá sociologická teorie koncepcí komunikace, kterou se společnosti samy „programuji““ tím, že diskurzivně vytvářejí různé formy sebepopisu i popisu světa, tj. různé formy vědění, jimiž je fungování společnosti orientováno.

Teorie, které takto chápou problém autogeneze, jsou ovšem zároveň konfrontovány $\mathrm{s}$ tím, co jsme s Luhmannem nazvali problémem autologickým, plynoucím z toho, že i sociologické sebepopisy společnosti jsou její součástí. Tento problém není samožrejmě Luhmannovým objevem. Již Mannheimova klasická sociologie vědění vycházela z toho, že vědění - a tedy sociologie sama - je vždy částí historicko-sociálních společenských formací, a je tedy podmíněno sociální lokalizací svého vzniku. Mannheim (1969: 239 nn.) teoreticky tento problém řešil svým relacionálním pojetím pravdivosti výpovědí, dle kterého je platnost výpovědí sociologické teorie daná jen v rámci diskurzu, jehož částí tyto výpovědi jsou. Ačkoliv byla tato problematika původně vnímána jako metodologická otázka specifická pro sociologii vědění (Šrubař 2010), ukázalo se záhy, že se jedná o všeobecný problém tvorby sociologických teorií, které musí reflektovat vztah konstrukce svých výpovědí ke svému předmětu.

I zde nacházíme několik typických řešení. Jedno z prvních je obsaženo již ve Weberově novokantovské koncepci ideálních typů a bylo později převzato i Parsonsem. Teoretické koncepty zde mají charakter teoretických experimentů konstruujících modely sociální skutečnosti, ,jako by“ se tato řídila axiomy do ní experimentálně vloženými, tj. jako by organizace byly racionální, jako by společnosti přestavovaly systémy jednání v dynamické rovnováze atd. Konfrontací modelu s empirickou skutečností je pak možno „vložit“ do nepřehledného toku pozorovaného sociálního života logickou strukturu (Weber 1972: 9 nn.). Tvorba teorie zůstává tak v principu autonomní záležitostí teoretika, přičemž zůstává otevřeno, je-li společnost opravdu systémem atd. Tomu oponují modely interakcionistické, vycházející z Meadových a Schützových představ (klasicky Blumer 1969 a Garfinkel 1989 a jejich následovníci), které argumentují, že teorie může být adekvátní svému předmětu jen tehdy, když 
patřičně zohlední procesy interakce a komunikace, jimiž každodenní aktéři svou sociální realitu vytvářejí a interpretují. Modely sociální teorie musí tak ve své struktuře odpovídat strukturám „modelování“ skutečnosti v každodenním jednání. Touto formou může sociologická teorie metodologicky zpracovat fakt, že je částí svého předmětu a nikoliv konstruktem společnosti vnějším. Třetí typ řešení autologického problému, který je jistým zpo̊sobem generalizací Mannheimova př́stupu, nacházíme opět v teorii Luhmannově (1990). Sociologická teorie je zde chápána jako specifický typ komunikace o komunikaci v sociálních systémech, pomocí které je možno pozorovat, jak sociální systémy pozorují, přičemž samozřejmě toto pozorování druhého rádu může být samo pozorováno z jiných míst v sociálním systému atd. Sociologická teorie jako typ vědeckého sebepopisu systému v něm tak žádnou výhradní pozici nezaujímá, nýbrž je součástí jeho autogeneze vedle jiných možných sebepopisů.

Pokusme se nyní shrnout závěry, které o struktuře sociologických teorií můžeme ze shora řečeného vyvodit. Ukázalo se, že výstavba teorií není řízena jen logikou jejich axiomů, ale i volbou výchozí roviny v kruhu autogeneze sociální reality, a je tedy podmíněna i strukturou předmětu sociologie, jehož jsou teorie součástí. Na základě této kongruence jsou teorie ve svých možnostech vysvětlování vázány na socio-historickou strukturu svého předmětu, která jim ,předkládá“ jednak věcné problémy, jednak možné přístupy k jejich řešení, vznikající „pozorováním“ toho, jakou praxí, jakými sebepopisy a jakou komunikací se jejich předmět - společnost - sama ,pozoruje“ a konstruuje. Tento moment relativismu ve výpovědi sociologických teorií není pouze jakousi nevýhodou, která omezuje jejich platnost. Je v něm totiž zároveň zakotvena možnost adekvátního uchopení sociální reality, s níž jsou teorie takto strukturně spojeny. To ovšem neznamená, že jsou sociologické teorie na základě tohoto zakotvení jednoduchým zrcadlením či technickým popisem fungování společenské mašinerie. Platí-li, řečeno s Luhmannem, že sociální systémy operují na základě smyslu, ${ }^{6}$ pak jsou sociologické teorie vždy výkladem, což už samo o sobě nutně zahrnuje možnost plurality pohledů. Pro metodologii jejich konstrukce to znamená, že mají vždy i hermeneutický charakter. Jsouce součástí cirkularity autogeneze sociální reality, nemohou vybočit ani z cirkularity hermeneutické - jejich výklad je vždy již výkladem smyslu vkládaného do sociální skutečnosti „laickými““ aktéry, přičemž se tato „laická“ interpretace ve společenském diskurzu s výkladem sociálních věd částečně prolíná a částečně mu konkuruje. Z faktu, že i „laičtí“ aktéři se ve společnosti orientují, že jí rozumí a - někdy úspěšně jednají, vyplývá pak společenská skepse k výhradnosti sociologických analýz, kterou pozorujeme v mnohých oblastech společenského života. Předností sociologické teorie před každodenním pozorováním je tedy jen to, že má proti němu relativní náskok, spočívající v její pozici pozorovatelky druhého stupně. Je tak schopna vidět, co aktéři sice praktikují, ale pro samozrrejmost své praxe nevidí. Ale ani to nepřispívá k její společenské oblibě. Již Parsons (1966) měl za to, že společenské hodnoty jako motivace jednání fungují nejlépe, zůstávají-li v kolektivní zásobě vědění latentní. Stanou-li se předmětem společenského

6 Tento předpoklad sdílí překvapivě skoro všechna současná teoretická paradigmata, počínaje teoriemi jednání at' už interpretativního či nomologického charakteru, přes Giddense, Bourdieua, široké pole postmoderny a cultural studies až po sytémové teorie parsonsovské nebo luhmannovské provenience. 
diskurzu, mizí jejich jednoznačnost, a tím i samozřejmá platnost. Vyzvedat samozřejmé společenské mechanismy na světlo a analyzovat jejich fungování je však právě úkolem sociologických teorií. Jejich z toho plynoucí prekérní společenské postavení je tak i indikátorem jejich autologické a hermeneutické pozice.

Je ovšem třeba zdůraznit, že ne všechny sociologické výklady lze považovat za teorie, a to ani tehdy, jestliže tento nárok samy pozvedají. Primárním kritériem by zde mělo být to, zdali tyto výklady vůbec obsahují výpovědi dotýkající se alespoň některých z uvedených šesti základních otázek, ke kterým teorie musí zaujmout stanovisko. Ale i zde je třeba rozlišovat mezi rovinami, na kterých se tyto výpovědi pohybují. Na jedné straně se v rámci pojednávaných otázek může jednat o analytické soudy týkající se konkrétních fenoménů, na straně druhé pak o výpovědi o konstrukci teoretického instrumentária, na jehož základě je analýza prováděna. Sociologické narativy často samozřejmě pojednávají i na rovině věcných výpovědí o motivaci jednání, složení sociální struktury či o procesech sociálních změn atd. Mohou-li tím zároveň pozvedat i teoretický nárok, záleží na tom, jakým způsobem zohledňují teoretický horizont, na jehož pozadí se tak děje. Teprve explicitní pokus o systematické řešení alespoň některých z uvedených problémů plynoucích z otázky ,jak je společnost možná?“, činí ze sociologického výkladu výklad teoretický. ${ }^{7}$ Tímto rozlišením není samozřejmě řečeno nic o kvalitě daného sociologického narativu. Existují zajisté fundované analýzy aktuálních společenských problémů stojící vedle málo přesvědčivých teoretických konstrukcí, a naopak. Kritizovatelnost sociologických výkladů závisí vždy i na rozlišení rovin argumentace, o niž se jejich validita opírá. Jen tak lze posoudit, jakým způsobem zajištují adekvátnost svých vývodů ve vztahu ke svému předmětu. To je pak podstatným momentem pro posouzení potenciálu jimi předkládaných vysvětlení, popřípadě pro jejich falsifikaci. Předložená úvaha slouží tomuto účelu.

\section{Literatura}

BECK, Ulrich. Risikogesellschaft. Frankfurt/M: Suhrkamp, 1992. 391 s. ISBN 3-518-11365-8.

BERGER, Peter L.; LUCKMANN, Thomas. The Social Construction of Reality. Garden City (NY): Doubleday, 1966. $203 \mathrm{~s}$.

BLUMER, Herbert. Symbolic Interactionism. Perspective and Method. Englewood Cliffs (N.J.): Prentice-Hall, 1969. 208 s. ISBN 0138799245.

7 Typickým př́kladem podnětných sociologických narativů, které nejsou teoriemi ve zde uváděném smyslu, jsou sociologické diagnózy proměn společnosti jako Beckova Riziková společnost (Beck 1992), Boltanského a Chiapellův Nový duch kapitalismu (Boltanski a Chiapello 2006) nebo Lyotardovo Postmoderní vědění (Lyotard 1985). Ani rekonstrukce historického vývoje jisté společnosti jako kupř́kladu Eliasův Proces civilizace (Elias 1997) nebo Weberova Protestantská etika a duch kapitalismu (Weber 2006) nejsou teoriemi potud, pokud se jejich pojmové instrumentárium vztahuje jen na historický př́ípad, který analyzují. Teoretická debata o těchto textech je možná teprve tehdy, spojíme-li je s obecnými výpověd’mi o mechanismech, které umožňují motivaci jednání, vznikání institucí atd., kupř́kladu s Eliasovými předpoklady z oblasti psychoanalýzy nebo s Weberovou teorií jednání. 
BOLTANSKI, Luc; CHIAPELLO, Ève. Der neue Geist des Kapitalismus. Konstanz: UVK, 2006. 735 s. ISBN 3-89669-555-X.

BOURDIEU, Pierre. Die feinen Unterschiede. Frankfurt/M: Suhrkamp, 1984. 877 s. ISBN: 3518576623.

COLEMAN, James S. Foundations of Social Theory. Cambridge (MA): Belcamp Press, 1990. 3. sv. 993 s. ISBN 0-674-31225-2.

DURKHEIM, Emile. Les règles de la méthode sociologique. Paris: Alcan, 1895. $186 \mathrm{~s}$.

DURKHEIM, Emile. De la division du travail social. Paris: Presses Universitaires de France, 1960. $416 \mathrm{~s}$.

ELIAS, Norbert. Über den Prozeß der Zivilisation. Frankfurt/M: Suhrkamp, 1997, 2. sv. 1103 s. ISBN 3-518-27758-8.

ESSER, Hartmut. Alltagshandeln und Verstehen. Tübingen: Mohr, 1991. 110 s. ISBN 3-16-145834-6.

GARFINKEL, Harold. Studies in Ethnomethodology. Cambridge: Polity Press, 1989. 288 s. ISBN 0-7456-0005-0.

GIDDENS, Anthony. The Constitution of Society. Cambridge: Polity Press, 1999. 402 s. ISBN 0-7456-0007-7.

HABERMAS, Jürgen. Theorie des kommunikativen Handelns. Frankfurt/M: Suhrkamp, 1981. 2 sv. 1165 s. ISBN 3-518-07591-8.

HRADIL, Stefan. Sozialstrukturanalyse in einer fortgeschrittenen Gesellschaft, von Klassen und Schichten zu Lagen und Milieus. Opladen: Leske und Budrich, 1987. 213 s. ISBN 3-8100-0581-9.

KUHN, Thomas S. The Structure of Scientific Revolutions. Chicago: University of Chicago Press, 1996. 212 s. ISBN 0-226-45807-5.

LATOUR, Bruno. On Actor-Network Theory. A Few Clarifications. Soziale Welt, 1996, roč. 47, č. 3. s. 369-381. ISSN 0038-6073.

LATOUR, Bruno. Wir sind nie modern gewesen. Frankfurt/M: Suhrkamp, 2008. 205 s. ISBN 978-3-518-29461-1.

LUHMANN, Niklas. Wie ist soziale Ordnung möglich. In LUHMANN, N. Gesellschaftsstruktur und Semantik. Sv. II. Frankfurt/M: Suhrkamp, 1981, s. 195-286. ISBN 3-518-07551-9.

LUHMANN, Niklas. Soziale Systeme. Frankfurt/M: Suhrkamp, 1985. 674 s. ISBN 3-518-57684-4.

LUHMANN, Niklas. Die Wissenschaft der Gesellschaft. Frankfurt/M: Suhrkamp, 1990. 732 s. ISBN 3-518-58065-5.

LYOTARD, Jean-Francois. La condition postmoderne. Paris: Les Editions de Minuit, 1985. 109 s. ISBN 2707302767.

MANNHEIM, Karl. Ideologie und Utopie. Frankfurt/M: Schulte-Bulmke, 1969. $302 \mathrm{~s}$.

MEAD, George Herbert. Mind, self, and society. Chicago: University of Chicago Press, 1970. $401 \mathrm{~s}$.

PARETO, Vilfredo. Compendium of General Sociology. Minneapolis: University of Minneapolis Press, 1980. 471 s. ISBN 0-8166-0920-9.

PARSONS, Talcott. The Social System. Glencoe: The Free Press, 1951. 575 s.

PARSONS, Talcott. Essays in Sociological Theory. Glencoe: The Free Press, 1967. 459 s.

PARSONS, Talcott. Societies. Evolutionary and Comparative Perspectives. Englewood Cliffs (NJ): Prentice-Hall, 1966. $120 \mathrm{~s}$.

PARSONS, Talcott. The Structure of Social Action, New York: The Free Press, 1968. $470 \mathrm{~s}$.

PARSONS, Talcott, SHILS, Edward A., LAZARSFELD, Paul F. Soziologie - autobiographisch. 3 kritische Berichte zur Entwicklung einer Wissenschaft. Stuttgart: Enke, 1975. 232 s. ISBN 3-423-02193-9.

POPPER, Karl R. Logik der Forschung. Tübingen: Mohr, 1973. 441 s. ISBN 3-16-532711-4.

Projekt Klassenanalyse Materialien zur Klassenstruktur der BRD. Berlin: Institut für das Studium der Arbeiterbewegung, 1975. 144 s. ISBN 3-87975-068-8.

RICKERT, Heinrich. Die Grenzen der naturwissenschaftlichen Begriffsbildung. Tübingen: Mohr, 1913. $644 \mathrm{~s}$. 
SEDLÁČEK, Tomáš. Ekonomie dobra a zla. Praha: 65. pole, 2009. ISBN 987-80-903944-3-8.

SCHÜTZ, Alfred. Der sinnhafte Aufbau der sozialen Welt. Konstanz: UVK, 2004. 500 s. ISBN 3-89669-748-X.

SIMMEL, Georg. Soziologie, Berlin: Duncker und Humblot, 1968. 578 s.

SPENCER, Herbert. The Principles of Sociology. Vol. I. London: Williams \& Comp., 1885. $562 \mathrm{~s}$.

SRUBAR, Ilja. Lob der Angst vorm Fliegen. Zur Autogenese sozialer Ordnung. In SRUBAR, I. Phänomenologie und soziale Theorie, Wiesbaden: VS Verlag, 2007, s. 417-445. ISBN 978-3-531-14487-0.

SRUBAR, Ilja. Der Streit um die Wissenssoziologie. In KNEER, G., MOEBIUS, S. (eds.) Soziologische Kontroversen, Frankfurt/M: Suhrkamp, 2010, s. 46-78. ISBN 978-3-518-29548-9.

WEBER, Max. Wirtschaft und Gesellschaft. Tübingen: Mohr, 1972. 942 s. ISBN 3-16-533631-8.

WEBER, Max. Die protestantische Ethik und der Geist des Kapitalismus. München: Beck, 2006. 432 s. ISBN 3-406-51133-3.

\section{Autor}

Ilja Šrubař studoval sociologii, filozofii a historii v Praze a ve Frankfurtu nad Mohanem. Do roku 2009 byl profesorem sociologie na universitě v Erlangen. Zabývá se především sociologickými teoriemi, dějinami sociologie jakož i sociologií kultury a vědění. Poslední publikace: Phänomenologie und soziologische Theorie (Wiesbaden 2007), Kultur und Semantik (Wiesbaden 2009).

Kontakt: ilja.srubar@uni-konstanz.de 